\title{
Knowledge \& Practice of Radiation Exposure Protection Protocols by Dentists Performing Endodontic Treatment in Pakistan
}

\author{
Ramsha Kamran, Kiran Saba and Saima Azam
}

\section{ABSTRACT}

\begin{abstract}
Dental radiography is an essential diagnostic tool in endodontics and one of the indispensable indicators of success. However, the potentially harmful effects of radiation cannot be overlooked. The aim of this survey was to assess knowledge, attitude and practice of radiation hazards and exposure protection techniques of dentists in Pakistan. A cross-sectional study was conducted using an online survey questionnaire. The questionnaire was distributed among all regions of Pakistan through social media and WhatsApp after carrying out the reliability analysis. Statistical analysis was performed using SPSS 20.0. Question wise analysis using frequencies and percentages was done. Association between the level of awareness with qualification and workplace setting was carried out using chi-square test and logistic regression analysis. The minimum required sample size calculated for this study was 335. A total of 341 dentists [performing endodontic treatment] participated and submitted the form from all regions of Pakistan. $65 \%$ of the dentists were aware with the ALARA principle. $40 \%$ were aware with the ICRP and NCRP guidelines. Only $27 \%$ were using lead apron and $71.8 \%$ had never used thyroid collar on the patient. Furthermore, a positive correlation was seen between the designation and awareness level and practice $[p=0.01]$. Similarly, a significant correlation $p=0.01$ was seen between awareness level/practice and workplace setting. The results of the present study can help design continual education programs at regular intervals at institutional and national level for strict observance of radiation protection guidelines with more emphasis on general practitioners and government hospitals.
\end{abstract}

Keywords: Dentists, endodontics, knowledge, X-Rays, Pakistan, radiation protection.

\section{INTRODUCTION}

X-rays have been a very important diagnostic method in modern dentistry, ever since their discovery by Wilhelm Conrad Roentgen in 1895 [1]. The ability of the ionizing radiation to penetrate the soft tissue and reflecting an image which cannot be seen on a sensor by naked human eye gives it great importance in multiple branches of dentistry. The usage of radiographs varies from diagnosing minor carious lesions to periapical lesions of odontogenic and nonodontogenic origin [2] and for evaluation of cases for a better treatment planning [3]. Ionizing radiation, nevertheless, could be biologically damaging to the living tissues [4]. It can cause side effects by directly damaging the DNA of the living cell or indirectly by formation of free radicals. These unstable and reactive molecules tend to stabilize by rebinding and results in the formation of new toxic substances like hydrogen peroxide $\left[\mathrm{H}_{2} \mathrm{O}_{2}\right]$, which can cause cellular alterations [5].

The effects of X-ray radiation on humans are due to interactions at atomic levels [6]. These biological effects can be classified into two categories: deterministic and stochastic effects [7]. In deterministic effects, the severity of the response is proportional to the dose. There is a dose threshold above which damaging insult starts to appear and below which response is not seen [8]. By contrast, stochastic effects can occur even at low dose of radiation and leads to sublethal DNA damage [9]. This puts the patient and the operating personnel in a high-risk zone for the stochastic effects [7]. Ionizing radiations can have long term effects on different systems of the body. Such effects might appear as somatic effects or as genetic effects in the next generation [10]. There is definitely no threshold level of radiation exposure for the development of cancer or genetic effects to occur. The probability of developing cancer or genetic effects doubles with doubling the radiation dose [11].

It is generally believed that the risk of radiation associated with dental radiography, especially intraoral radiography, is not significantly greater than other everyday risks in life [11]. However, the degree of effect following the diagnostic level of $\mathrm{x}$-ray radiations is something that is not known for certain [12]. In endodontics, multiple radiographic images are required during the treatment to achieve ideal results [2] 
which can lead to cell injury, hyperplasia and ultimately development of tumor due to cumulative effect of radiation dose [4]. Therefore, the radiation exposure and dosage received by the patient coming for an endodontic treatment is significantly more, which in turn means there is a greater risk for the patient along with the healthcare provider if proper precautions are not taken [2].

Restriction guidelines on the amount of radiation exposure to both the dentist and the patients has been introduced by National Council on Radiation Protection \& Measurements [NCRP] and the International Commission on Radiological Protection [ICRP] since 1977 [3]. This risk/benefit concept recommends that all radiation exposure must be justified and kept as low as possible. It is therefore mandatory to follow the ALARA principle "as low as reasonably achievable" during our routine clinical work [9]. The dentists should take every possible measure to lower or eliminate unnecessary radiation exposure towards their patients and staff. Newer technologies such as digital radiography have been introduced which is rapidly growing and coming into practice. Digital radiography has distinct environmental advantages and most importantly it lowers the radiation exposure [13], [14]. In addition, serious efforts should be made to use thyroid collar, lead apron, high speed films and proper angulation while taking radiographs in order to reduce the risk of radiation exposure towards the patients [3].

There are high concerns about the radiation protection knowledge and practice of dental practitioners especially due to repeated examinations and the variety of radiographs during the procedures which leads to high cumulative radiation doses [3]. Therefore, the aim of this study was to evaluate the knowledge, attitude and practice of radiation hazards and exposure protection techniques by dentists performing endodontic treatment in Pakistan.

\section{MATERIALS AND Methods}

A cross sectional survey was conducted using an online survey questionnaire from 5th to 26th August 2021. The minimum required sample size calculated for this study was 335 with $95 \%$ confidence interval and $5 \%$ margin of error. Ethical approval was obtained from Institute's Research \& Ethics Committee.

The questionnaire was designed on Google Forms and reliability analysis was undertaken by carrying out a pilot survey initially. The intra-class correlation showed a strong relation of 0.81 . All the central locations of Pakistani dentists were identified on social media and WhatsApp groups in order to achieve maximum possible outreach in all the regions of Pakistan. The questionnaire was posted on all identified forums.

A structured questionnaire was prepared to assess the knowledge and practice of radiation hazards and exposure protection techniques by dentists performing endodontic treatment in Pakistan. The questionnaire was in the form of multiple-choice questions and was divided into three sections: socio-demographic data [gender, age, workplace setting and years of clinical experience], assessment of awareness, knowledge and practice of dentists towards dental radiography. The questions were adapted from the questionnaire used in study conducted by [2] among dentists in Saudi Arabia.

Data analysis was carried out using Statistical Package for the Social Sciences version 20.0 [SPSS 20.0]. Frequencies and percentages were calculated for qualitative variables. Question wise analysis in terms of percentages for each response was done. Chi square test was applied on each question for individual analysis. Association of awareness level and practice with qualification and workplace setting was evaluated using Pearson correlation and Kruskal Wallis $\mathrm{H}$ test respectively.

\section{RESULTS}

A total of 341 dentists participated and submitted the questionnaire from all regions of Pakistan. The questionnaire comprised of 24 questions in three sections. All questions were mandatory.

Table I shows the demographic information of the participants. Out of 341 participants, $48.1 \%$ were male and $51.9 \%$ were females. $38.7 \%$ were general practitioners, $27.6 \%$ were endodontic post-graduate students and $33.7 \%$ were consultants.

Table II shows practitioners' awareness and knowledge according to their education level. Endodontic consultants and post-graduate students showed better knowledge in most of the questions compared to the general practitioners performing endodontic treatment. Only $54 \%$ of the general practitioners were aware with the ALARA principle as compared to $70 \%$ of the consultants and $75 \%$ of post-graduate students. Regarding the knowledge of high-speed films, only $55 \%$ of the general practitioners were aware of the importance as compared to the $74 \%$ of the consultants/specialists. $75 \%$ of the consultants considered rectangular collimation to be better in reducing radiation exposure as compared to $44 \%$ of the general practitioners who thought round collimation is better.

Dentists working in private hospitals had better awareness towards radiation protection as compared to those working in clinics and government setup as shown in Table III.

\begin{tabular}{|c|c|c|}
\hline & & $\%$ \\
\hline \multirow{2}{*}{ Gender } & Male & 48.1 \\
\hline & Female & 51.9 \\
\hline \multirow{5}{*}{ Age } & $24-30$ & 39.6 \\
\hline & $31-35$ & 24.9 \\
\hline & $36-40$ & 20.8 \\
\hline & $41-45$ & 8.2 \\
\hline & $>45$ & 6.5 \\
\hline \multirow{3}{*}{ Qualification } & $\begin{array}{c}\text { General practitioner performing endodontic } \\
\text { treatment }\end{array}$ & 38.7 \\
\hline & $\begin{array}{l}\text { Operative dentistry and endodontic post } \\
\text { graduate student }\end{array}$ & 27.6 \\
\hline & $\begin{array}{c}\text { Operative dentistry and endodontic } \\
\text { consultant/specialist }\end{array}$ & 33.7 \\
\hline \multirow{4}{*}{$\begin{array}{c}\text { Years of } \\
\text { clinical } \\
\text { experience }\end{array}$} & 1-5 years & 39.9 \\
\hline & $6-10$ years & 32.8 \\
\hline & $11-15$ years & 14.7 \\
\hline & More than 15 years & 12.6 \\
\hline \multirow{3}{*}{ Workplace } & Government & 26.1 \\
\hline & Private hospital & 36.4 \\
\hline & Clinic & 37.5 \\
\hline
\end{tabular}


TABLE II: PRACTITIONERS' AWARENESS AND KNOWLEDGE TOWARDS RADIATION PROTECTION ACCORDING TO THEIR EDUCATIONAL LEVEL

\begin{tabular}{|c|c|c|c|c|c|}
\hline & & \multicolumn{4}{|c|}{ Education Level } \\
\hline & & $\begin{array}{l}\text { General practitioner } \\
\text { performing endodontic } \\
\text { treatment }[\%]\end{array}$ & $\begin{array}{l}\text { Operative dentistry } \\
\text { and endodontic } \\
\text { post graduate } \\
\text { student }[\%]\end{array}$ & $\begin{array}{c}\text { Operative dentistry } \\
\text { and endodontic } \\
\text { consultant/specialist } \\
{[\%]}\end{array}$ & $\mathrm{P}$-value \\
\hline \multirow{2}{*}{$\begin{array}{l}\text { Are you familiar with the ALARA } \\
\text { principle? }\end{array}$} & Yes & 54.5 & 75.5 & 70.4 & \multirow{2}{*}{$0.002^{*}$} \\
\hline & No & 45.5 & 24.5 & 29.6 & \\
\hline $\begin{array}{c}\text { Are you familiar with the } \\
\text { recommendations of the NCRP and } \\
\text { ICRP? }\end{array}$ & Yes & 25.8 & 42.6 & 53.9 & $0.000^{*}$ \\
\hline \multirow{3}{*}{$\begin{array}{l}\text { Does digital radiography require less } \\
\text { exposure than conventional? }\end{array}$} & Yes & 68.2 & 79.8 & 83.5 & \multirow{3}{*}{$0.023 *$} \\
\hline & No & 5.3 & 6.4 & 5.2 & \\
\hline & I don't know & 26.5 & 13.8 & 11.3 & \\
\hline \multirow{3}{*}{ Do high speed films reduce exposure? } & Yes & 55.0 & 64.9 & 74.0 & \multirow{3}{*}{$0.012^{*}$} \\
\hline & No & 9.4 & 7.4 & 10.3 & \\
\hline & I don't know & 35.6 & 27.7 & 15.7 & \\
\hline \multirow{2}{*}{$\begin{array}{l}\text { Specify the importance of the use of } \\
\text { collimators and filters in dental } \\
\text { radiography? }\end{array}$} & $\begin{array}{c}\text { Moderately } \\
\text { important }\end{array}$ & 23.5 & 9.6 & 13.0 & \multirow[t]{2}{*}{$0.034 *$} \\
\hline & Unimportant & 3.0 & 1.1 & 2.6 & \\
\hline \multirow{2}{*}{$\begin{array}{l}\text { Which collimator helps in reducing the } \\
\text { patient's exposure? }\end{array}$} & Round & 444.0 & 36.2 & 25.0 & \multirow{2}{*}{$0.021^{*}$} \\
\hline & Rectangular & 56.0 & 63.8 & 75.0 & \\
\hline \multirow{4}{*}{$\begin{array}{l}\text { What is the ideal distance of operator } \\
\text { Position Distance Rule when exposed to } \\
\text { dental radiography? }\end{array}$} & $\begin{array}{c}4 \mathrm{ft}, 90^{\circ} \text { to } \\
135^{\circ}\end{array}$ & 14.4 & 13.8 & 7.8 & \multirow{4}{*}{$0.000^{*}$} \\
\hline & $4 \mathrm{ft}, 60^{\circ}$ to $90^{\circ}$ & 12.9 & 8.5 & 1.7 & \\
\hline & $\begin{array}{c}6 \mathrm{ft}, 90^{\circ} \text { to } \\
135^{\circ}\end{array}$ & 42.4 & 58.5 & 70.4 & \\
\hline & $6 \mathrm{ft}, 60^{\circ}$ to $90^{\circ}$ & 30.3 & 19.1 & 20.0 & \\
\hline
\end{tabular}

$*$ Significant at $\mathrm{P}<0.05$. \&e same superscript letters indicate no significant differences $[\mathrm{P}>0.05]$.

TABLE III: PRACTITIONERS' AWARENESS AND KNOWLEDGE TOWARDS RADIATION PROTECTION ACCORDING TO THEIR WORKING AREA

\begin{tabular}{|c|c|c|c|c|c|}
\hline & & \multicolumn{4}{|c|}{ Working Area } \\
\hline & & $\begin{array}{c}\text { Government } \\
{[\%]}\end{array}$ & $\begin{array}{c}\text { Private } \\
\text { hospital }[\%]\end{array}$ & $\begin{array}{c}\text { Clinic } \\
{[\%]}\end{array}$ & $\mathrm{P}$-value \\
\hline \multirow{2}{*}{ Are you familiar with the ALARA principle? } & Yes & 62.9 & 74.2 & 59.4 & \multirow{2}{*}{$0.038 *$} \\
\hline & No & 37.1 & 25.8 & 40.6 & \\
\hline \multirow{2}{*}{ Are you familiar with the recommendations of the NCRP and ICRP? } & Yes & 39.3 & 44.4 & 35.9 & \multirow{2}{*}{0.391} \\
\hline & No & 60.7 & 55.6 & 64.1 & \\
\hline \multirow{3}{*}{ Does digital radiography require less exposure than conventional? } & Yes & 77.5 & 78.2 & 74.2 & \multirow{3}{*}{0.215} \\
\hline & No & 5.6 & 8.1 & 3.1 & \\
\hline & I don't know & 16.9 & 13.7 & 22.7 & \\
\hline \multirow{3}{*}{ Do high speed films reduce exposure? } & Yes & 68.5 & 66.1 & 60.2 & \multirow{3}{*}{0.400} \\
\hline & No & 5.6 & 7.3 & 12.5 & \\
\hline & I don't know & 25.8 & 26.6 & 27.3 & \\
\hline \multirow{3}{*}{$\begin{array}{l}\text { Specify the importance of the use of collimators and filters in dental } \\
\text { radiography? }\end{array}$} & Very important & 76.4 & 88.7 & 78.1 & \multirow{3}{*}{$0.011 *$} \\
\hline & $\begin{array}{l}\text { Moderately } \\
\text { important }\end{array}$ & 23.6 & 9.7 & 17.2 & \\
\hline & Unimportant & 0.0 & 1.6 & 4.7 & \\
\hline \multirow{2}{*}{ Which collimator helps in reducing the patient's exposure? } & Round & 32.6 & 33.9 & 40.6 & \multirow{2}{*}{0.390} \\
\hline & Rectangular & 67.4 & 66.1 & 59.4 & \\
\hline \multirow{4}{*}{$\begin{array}{l}\text { What is the ideal distance of operator Position Distance Rule when exposed to } \\
\text { dental radiography? }\end{array}$} & $4 \mathrm{ft}, 90^{\circ}$ to $135^{\circ}$ & 11.2 & 10.5 & 14.1 & \multirow{4}{*}{0.356} \\
\hline & $4 \mathrm{ft}, 60^{\circ}$ to $90^{\circ}$ & 12.4 & 8.9 & 3.9 & \\
\hline & $6 \mathrm{ft}, 90^{\circ}$ to $135^{\circ}$ & 53.9 & 58.9 & 55.5 & \\
\hline & $6 \mathrm{ft}, 60^{\circ}$ to $90^{\circ}$ & 22.5 & 21.8 & 26.6 & \\
\hline
\end{tabular}

$*$ Significant at $\mathrm{P}<0.05$. \&e same superscript letters indicate no significant differences $[\mathrm{P}>0.05]$.

Table IV shows practitioners' attitude and practice towards radiation protection according to their education level. Results showed that the endodontic consultants were best in following the radiation protection measures as compared to post-graduate students and general practitioners.
Table V shows practitioners' attitude and practice towards radiation protection according to their working area. Results show that practitioners working in the government setup lack adherence to the radiation protection protocols as compared to the clinics and private setup. 
TABLE IV: PRACTITIONERS' ATTITUDE AND PRACTICE TOWARDS RADIATION PROTECTION ACCORDING TO THEIR EDUCATIONAL LEVEL

\begin{tabular}{|c|c|c|c|c|c|}
\hline & & \multicolumn{4}{|c|}{ Educational level } \\
\hline & & $\begin{array}{l}\text { General practitioner } \\
\text { performing endodontic } \\
\text { treatment }\end{array}$ & $\begin{array}{l}\text { Operative dentistry } \\
\text { and endodontic post } \\
\text { graduate student }\end{array}$ & $\begin{array}{c}\text { Operative dentistry and } \\
\text { endodontic } \\
\text { consultant/specialist }\end{array}$ & $\mathrm{P}$-value \\
\hline \multirow{3}{*}{$\begin{array}{l}\text { Do you use lead apron for patients } \\
\text { during exposure? }\end{array}$} & Frequently & 22.0 & 16.0 & 41.7 & \multirow{3}{*}{$0.000 *$} \\
\hline & Occasionally & 33.3 & 38.3 & 20.9 & \\
\hline & Never & 44.7 & 45.7 & 37.4 & \\
\hline \multirow{2}{*}{$\begin{array}{l}\text { Do you use thyroid collar for } \\
\text { patients during exposure? }\end{array}$} & Frequently & 6.8 & 6.4 & 15.7 & \multirow{2}{*}{0.125} \\
\hline & Never & 73.5 & 75.5 & 67.0 & \\
\hline \multirow{3}{*}{$\begin{array}{l}\text { Do you ask patients to hold the film } \\
\text { while taking radiographs? }\end{array}$} & Frequently & 31.8 & 38.3 & 28.7 & \multirow{3}{*}{0.112} \\
\hline & Occasionally & 34.1 & 41.5 & 34.8 & \\
\hline & Never & 34.1 & 20.2 & 36.5 & \\
\hline \multirow{3}{*}{$\begin{array}{l}\text { Do you stand directly in the path of } \\
\text { the primary radiation? }\end{array}$} & Frequently & 24.2 & 34.0 & 18.3 & \multirow{3}{*}{$0.004^{*}$} \\
\hline & Occasionally & 31.1 & 34.0 & 23.5 & \\
\hline & Never & 44.7 & 31.9 & 58.3 & \\
\hline \multirow{2}{*}{$\begin{array}{l}\text { Do you stand behind a lead barrier } \\
\text { during exposure? }\end{array}$} & Occasionally & 25.0 & 26.6 & 19.1 & \multirow[t]{2}{*}{$0.003^{*}$} \\
\hline & Never & 54.5 & 58.5 & 43.5 & \\
\hline \multirow{3}{*}{$\begin{array}{c}\text { If within the same area do you stand } \\
6 \mathrm{ft} \text { away from primary x-ray beam } \\
\text { during exposure? }\end{array}$} & Frequently & 23.5 & 23.4 & 45.2 & \multirow{3}{*}{$0.002 *$} \\
\hline & Occasionally & 41.7 & 40.4 & 32.2 & \\
\hline & Never & 34.8 & 36.2 & 22.6 & \\
\hline \multirow{3}{*}{$\begin{array}{l}\text { Do you hold the film in the patients } \\
\text { mouth during exposure? }\end{array}$} & Frequently & 55.3 & 47.9 & 39.1 & \multirow{3}{*}{$0.048 *$} \\
\hline & Occasionally & 26.5 & 34.0 & 30.4 & \\
\hline & Never & 18.2 & 18.1 & 30.4 & \\
\hline \multirow{3}{*}{$\begin{array}{c}\text { Do you stay within the same clinic } \\
\text { during x-ray exposure? }\end{array}$} & Frequently & 70.5 & 64.9 & 50.4 & \multirow{3}{*}{$0.003 *$} \\
\hline & Occasionally & 19.7 & 26.6 & 27.0 & \\
\hline & Never & 9.8 & 8.5 & 22.6 & \\
\hline \multirow{3}{*}{$\begin{array}{c}\text { If you decide to stay within the } \\
\text { same clinic during x-ray exposure, } \\
\text { do you use lead apron on a regular } \\
\text { basis? }\end{array}$} & Frequently & 14.4 & 5.3 & 24.3 & \multirow{3}{*}{$0.0005^{*}$} \\
\hline & Occasionally & 23.5 & 27.7 & 21.7 & \\
\hline & Never & 62.1 & 67.0 & 53.9 & \\
\hline $\begin{array}{l}\text { Do you allow people to come inside } \\
\text { the room during exposure to x-ray? }\end{array}$ & Never & 43.2 & 41.5 & 60.9 & $0.022 *$ \\
\hline
\end{tabular}

* Significant at $\mathrm{P}<0.05$. \&e same superscript letters indicate no significant differences $[\mathrm{P}>0.05]$.

TABLE V: PRACTITIONERS' ATTITUDE AND PRACTICE TOWARDS RADIATION PROTECTION ACCORDING TO THEIR WORKING AREA

\begin{tabular}{|c|c|c|c|c|c|}
\hline & & \multicolumn{4}{|c|}{ Q44. Which practice do you work in? } \\
\hline & & Government & Private hospital & Clinic & $\mathrm{P}$-value \\
\hline \multirow{3}{*}{ Do you use lead apron for patients during exposure? } & Frequently & 16.9 & 25.0 & 35.9 & \\
\hline & Occasionally & 29.2 & 40.3 & 21.9 & $0.001 *$ \\
\hline & Never & 53.9 & 34.7 & 42.2 & \\
\hline \multirow{3}{*}{ Do you use thyroid collar for patients during exposure? } & Frequently & 3.4 & 8.9 & 14.8 & \\
\hline & Occasionally & 20.2 & 21.8 & 14.1 & $0.043 *$ \\
\hline & Never & 76.4 & 69.4 & 71.1 & \\
\hline \multirow[t]{2}{*}{ Do you ask patients to hold the film while taking radiographs? } & Occasionally & 43.8 & 38.7 & 28.9 & 0.127 \\
\hline & Never & 25.8 & 27.4 & 38.3 & \\
\hline \multirow{3}{*}{ Do you stand directly in the path of the primary radiation? } & Frequently & 23.6 & 26.6 & 24.2 & \\
\hline & Occasionally & 39.3 & 25.0 & 26.6 & 0.173 \\
\hline & Never & 37.1 & 48.4 & 49.2 & \\
\hline \multirow[b]{2}{*}{ Do you stand behind a lead barrier during exposure? } & Frequently & 11.2 & 30.6 & 28.1 & \\
\hline & Occasionally & 30.3 & 19.4 & 22.7 & $0.013 *$ \\
\hline \multirow{3}{*}{$\begin{array}{l}\text { If within the same area do you stand } 6 \mathrm{ft} \text { away from primary x-ray beam during } \\
\text { exposure? }\end{array}$} & Frequently & 16.9 & 37.1 & 34.4 & \\
\hline & Occasionally & 49.4 & 30.6 & 37.5 & $0.010 *$ \\
\hline & Never & 33.7 & 32.3 & 28.1 & \\
\hline \multirow{3}{*}{ Do you hold the film in the patients mouth during exposure? } & Frequently & 52.8 & 46.8 & 45.3 & \\
\hline & Occasionally & 34.8 & 28.2 & 28.1 & 0.134 \\
\hline & Never & 12.4 & 25.0 & 26.6 & \\
\hline \multirow{3}{*}{ Do you stay within the same clinic during $x$-ray exposure? } & Frequently & 65.2 & 60.5 & 61.7 & \\
\hline & Occasionally & 29.2 & 25.8 & 18.8 & $0.037 *$ \\
\hline & Never & 5.6 & 13.7 & 19.5 & \\
\hline \multirow{3}{*}{$\begin{array}{l}\text { If you decide to stay within the same clinic during x-ray exposure, do you use lead } \\
\text { apron on a regular basis? }\end{array}$} & Frequently & 7.9 & 12.1 & 23.4 & \\
\hline & Occasionally & 21.3 & 26.6 & 23.4 & $0.011^{*}$ \\
\hline & Never & 70.8 & 61.3 & 53.1 & \\
\hline \multirow{3}{*}{ Do you allow people to come inside the room during exposure to $\mathrm{x}$-ray? } & Frequently & 33.7 & 21.8 & 19.5 & \\
\hline & Occasionally & 33.7 & 27.4 & 22.7 & $0.007 *$ \\
\hline & Never & 32.6 & 50.8 & 57.8 & \\
\hline
\end{tabular}




\section{Discussion}

Over the past few decades, the use of dental radiography has been significantly increased [3]. This has led to improved diagnosis and treatment planning but is also associated with increased risk of undesirable exposure to the operator and the patient. Although it is generally believed that the risk of radiation exposure with dental radiography is less but there is still possibility of hazard since even with a small dose stochastic effects may result [6]. Therefore, this has led to the concept of ALARA "as low as reasonably achievable".

Regarding the awareness and knowledge of practitioners towards radiation protection, $74.2 \%$ of the general practitioners were unaware of the NCRP and ICRP recommendations compared to $46 \%$ of the consultants and $57 \%$ of the post-graduate students. In dental radiography, it is known that a rectangular collimator can reduce radiation exposure by $60 \%$ compared with a round collimator [15]. In the present study, $75 \%$ of the consultants thought rectangular collimation is better compared to $56 \%$ of the general practitioners. This is in contrast to a previous study in South Africa where only $20 \%$ of the specialists were aware that rectangular collimation is better [15]. This could be due to the fact that the current curriculum of South African dental students included rigorous training in oral and dental radiology.

The ideal distance of operator position distance rule according to the principle of ALARA is $6 \mathrm{ft}, 90^{\circ}$ to $135^{\circ}$. In the current study, only $42.4 \%$ of the general practitioners were aware of the ideal position compared to $70.4 \%$ of the specialists. In the current study, post-graduate students and consultants showed better awareness as compared to the general practitioners. This could be due to the fact that most of the consultants and post-graduate residents being part of the academic sector are up to date in their knowledge. The results were similar to previous studies which showed that level of awareness was directly related to the level of education, with consultants having better awareness as compared to the general practitioners [2], [16], [17].

Radiation protection guidelines by NCRP, ICRP and American Dental Association has made it mandatory to use thyroid collar on patients and the use of lead apron if other recommendations are not rigorously followed. Several studies have reported increased risk of thyroid cancer associated with repeated exposures to dental x-rays [2]. In the current study, $41.7 \%$ of the endodontic consultants were using lead apron on patients compared to $16 \%$ post-graduate students and $22 \%$ general practitioners. $15.7 \%$ were using thyroid collars on patients compared to only $6.4 \%$ and $6.8 \%$ of the post-graduate students and general practitioners respectively.

The overall results of the current study revealed that consultants/specialists had better attitude and practice compared to post-graduate students and general practitioners. Although, the percentage of specialists having thorough knowledge regarding radiation protection was good, application in clinical practice was relatively low e.g., $70 \%$ of the consultants were aware of the safe distance from the primary radiation but only $45 \%$ of them were applying it in their clinical practice.

Practitioners working in the government sector had poor awareness and practice compared to private hospitals and clinics. One of the significant findings was a positive correlation between the awareness level and workplace setting showing that the doctors of private hospitals had more mean awareness score and practice as compared to the doctors of government setup. The main reason for this correlation could be due to increased scrutiny and accountability in private hospitals as governing bodies/shareholders are conscious about the repute of their setup.

One of the limitations of our study was that under-graduate students were not included. Another limitation was that the number of respondents varied among working sectors/area and were not equally distributed.

The knowledge and practice of radiation protection was fair in the endodontic consultants and private hospitals. The current study provides valuable data for developing courses to improve knowledge and awareness especially among general practitioners and government setups and to help apply the knowledge in their clinical practice.

\section{ACKNOWLEDGMENT}

We want to thank all the faculty of Islamabad Medical and Dental College for their support.

\section{FUNDING}

No funding was obtained for the study.

\section{CONFLICT OF INTEREST}

Authors declare that they do not have any conflict of interest.

\section{REFERENCES}

[1] Jones CG. A review of the history of US radiation protection regulations, recommendations, and standards. Health Physics. 2005; 88(2): 105-24.

[2] Almohaimede AA, Bendahmash MW, Dhafr FM, Awwad AF, AlMadi EM. Knowledge, attitude, and practice [KAP] of radiographic protection by dental undergraduate and endodontic postgraduate students, general practitioners, and endodontists. Int J Dent. 2020; 2020 .

[3] Binti Abd Rahman F, Gurunathan D, Vasantharajan MS. Knowledge, attitude and practice of radiation exposure protection for pediatric patients among undergraduate dental students. Biomed. Pharmacol. J. 2018; 11(2): 1143-51.

[4] Ribeiro DA, De Oliveira G, De Castro GM, Angelieri F. Cytogenetic biomonitoring in patients exposed to dental X-rays: comparison between adults and children. Dentomaxillofac Radiol. 2008; 37(7): 404-7.

[5] Lannucci MJ, Howerton LJ. Dental radiography: principles and techniques. 5th Ed. St. Louis: Elsevier; 2012: 12-20.

[6] Rabhat MP, Sudhakar S, Kumar BP, Ramaraju. Knowledge, attitude and perception [KAP] of dental undergraduates and interns on radiographic protection-a questionnaire based cross-sectional study. $J$ Adv Oral Res. 2011; 3(3): 45-50.

[7] Mallya MS, Lam WNE. White and pharoah's oral radiology principles and interpretation. 7th Ed. St. Louis: Elsevier; 2004: 25-46.

[8] Frommer HH. Biological effects of radiation, in radiology for dental auxiliaries. 6thEd. St. Louis: Elsevier; 1996: 49-67.

[9] Arnout EA, Jafar A. Awareness of biological hazards and radiation protection techniques of dental imaging-a questionnaire based crosssectional study among Saudi dental students. J Dent Health Oral Disord Ther. 2014; 1(1): 1-7. 
[10] Amirzadeh, F, Tabatabaee SH. Evaluation of healthy behavior in radiation employees in hospitals of Shiraz. The Fourth International Cyberspace Conference on Ergonomics. 2005.

[11] Basheer B, Albawardi KW, Alsanie SA, Alotaibi BM, Alanazi MM, Alfaifi HA, et al. Knowledge, attitudes and perception toward radiation hazards and protection among dental professionals in Riyadh, Kingdom of Saudi Arabia. Int. J. Med. Health Res. 2019; 8(9): 75-81.

[12] Bushong CS. Radiologic science for technologists: Physics, Biology and Protection. 11th Ed. St Louis: Elsevier; 2017: 483-90.

[13] Wenzel A, Gröndahl H. Direct digital radiography in the dental office. Int Dent J. 1995; 45: 27-34.

[14] Parks ET, Williamson GF. Digital radiography: an overview. $J$ Contemp Dent Pract. 2002; 3: 23-39.

[15] Vilborn P, Uys A, Yakoob Z, Cronje T. Evaluation of radiation awareness among oral health care providers in South Africa. S. Afr. Dent. J. 2021; 76(3): 122-8.

[16] Furmaniak KZ, Kołodziejska MA, Szopiński KT. Radiation awareness among dentists, radiographers and students. Dentomaxillofac Radiol. 2016; 45(8): 20160097.

[17] Svenson B, Söderfeldt B, Gröndahl H. Knowledge of oral radiology among Swedish dentists. Dentomaxillofac Radiol. 1997; 26(4): 219-24. 